\title{
Approaching of Financial Ratio Analysis of Canara Bank and ICICI Bank
}

\author{
D.O.I - 10.51201/Jusst12665 \\ http://doi.org/10.51201/Jusst12665 \\ Dr. Sony Hiremath* \\ Karnataka State Akkamahadevi Women's University \\ Vijayapur

\section{Dr. Veena Ishwarappa Bhavikatti**} \\ Assistant Professor \\ Central University of Karnataka \\ Kalaburgi
}

\begin{abstract}
A ratio is defined as 'the indicated quotient of two mathematical expressions' and as 'the relationship between two quantitative terms between figures which have a cause and effect relationship or which are connected with each other in some manner or the other. The sources of primary data are survey, observation and experimentation and secondary data collected through various websites. A noticeable point is that a ratio reflecting a quantitative relationship helps to perform a qualitative judgment; such is the nature of all financial ratios "Ratio can assist management in its basic functions of forecasting, planning coordination, control and communication". It is helpful to know about the liquidity, solvency, capital structure and profitability of an organization. It is helpful tool to aid in applying judgment, otherwise complex situations.
\end{abstract}

Keywords: Ratios, Financial Analysis, Liquidity, Capital structure, Profitability, Banks

\section{Introduction}

A ratio is simple one number expressed in terms of another number. In another word, a ratio expresses mathematical relationship between one number and another. Ratio analysis is a very powerful and most commonly used tool of financial analysis and interpretation of financial statements. It concentrates on inter -relationship among the figures appearing in the financial statements. Ratio analysis helps to analyze the past performance of a company and to make future projections. It allows various interested parties like management, shareholders, potential investors, creditors, government and other analysts to make an evolution of the various aspects of company's performance from their own point of view and interest. For example, management and shareholders may be interested in the company's profitability while creditors and debenture holders may be interested in the solvency of the company. Financial analysis is mainly done to compare the growth, profitability and financial soundness of the respective banks by diagnosing 
the information contained in the financial statements. Financial analysis is done to identify the financial strengths and weakness of the two banks by properly establishing relationship between the items of balance sheet and profit \& loss account. It helps in better understanding of banks financial position, growth and performance by analyzing the financial statements with various tools and evaluating the relationship between various elements of financial statements.

\section{Objectives of the study}

To study the financial performance of CANARA bank and ICICI bank.

$>$ To compare the financial performance of CANARA bank and ICICI bank.

\section{Statement of Problem}

Performance and efficiency of commercial banks are the key elements of efficiency and efficacy of countries' financial system. The broad objective of the banking sector reforms in India has been to increase efficiency and profitability of the banks. Prior to banking reforms, the industry was a near monopoly dominated by public sector banks. However, the banking reforms a number of private and foreign banks extend the market armed with greater autonomy. Operational efficiency is an indicator, which will help not only the public but to the management, regulators, and supervisors to understand and judge the relative efficiency of the players competing in the banking sector. Therefore, this study attempts to apply profitability ratios, solvency ratios, and management efficiency ratios of CANARA bank and ICICI bank in order to compare their efficiency and solvency position.

\section{Review of Literature}

Feroz \& et al. (2003) Ratio analysis is a commonly used analytical tool for verifying the performance of a firm. While ratios are easy to compute, which in part explains their wide appeal, their interpretation is problematic, especially when two or more ratios provide conflicting signals. Indeed, ratio analysis is often criticized on the grounds of subjectivity that, is the analyst must pick and choose ratios in order to assess the overall performance of a firm. In this paper they demonstrate that Data Envelopment Analysis (DEA) can augment the traditional ratio analysis. DEA can provide a consistent and reliable measure of managerial or operational efficiency of a firm. They test the null hypothesis that there is no relationship between DEA and traditional accounting ratios as measures of performance of a firm. Their results reject the null hypothesis indicating that DEA can provide information to analysts that is additional to that provided by traditional ratio analysis. They also apply DEA to the oil and gas industry to demonstrate.

Prasanta Paul (2011) reported that "Financial Performance Evaluation - A Comparative Study of Some Selected NBFCs". In this study, five listed NBFCs have been considered for analyzing comparative financial performance. Different statistical tools like, Arithmetic mean, Standard 
Deviation, Coefficient of Variance, Correlation and Analysis of Variance have been used extensively. Arithmetic Mean (AM) is an ideal measure of central tendency, which is rigidly defined, easy to calculate, based on all observations and affected least by fluctuations of sampling has been applied in this study. It has been used to get a stable average and it is easy to understand the results of the study. It concludes that the selected companies differ significantly in terms of their financial performance indicators from one to another, may be for the different services they provide. There are no significant differences in the last five years in the management of financial performance of each selected NBFCs, except marginal deviation in some cases in the year 2006-07 may be for the effect of general recession in that period.

Vivek Kumar and Major Singh (2013) conducted a study on "Profitability of Indian Banks - A Comparative Study of SBI and HDFC". The study revealed that the various profitability . ratios of two banks as the measure of profitability. The common denominator used for developing the various profitability ratios is business volume (deposits plus advances). The study analyses the published five-year data from 2007-08 onwards for the two largest banks, i.e., SBI- the largest public-sector bank and HDFC- the largest private sector bank. The comparative analysis of the profitability of the two banks clearly reveals that there is a large difference between the profitability of the two banks.

\section{Research methodology}

In the present study, an attempt has been made to measure, evaluate and compare the financial performance of CANARA bank and ICICI bank which one related to the public sector and private sector respectively. The study is based on secondary data that has been collected from annual reports of the respective banks, magazines, journals, documents and other published information. The study covers the period of 5 years i.e. from year 2012-13 to year 2016-17. Ratio analysis was applied to analyze and compare the trends in banking business and financial performance.

Primary data are the first-hand data collected for the study on ratio Analysis. The sources of primary data are survey, observation and experimentation.

Secondary data are data published or unpublished, which have already been collected and processed by some agencies for their statistical work, are termed as secondary data as far as second agency is concerned. It also includes Journals, ledgers, book of various authors, company's various websites. Etc. \& there is no sampling used in this study. The data used in this research is secondary data. 


\section{A\}LIQUID RATIO}

\section{Current ratio}

\begin{tabular}{|l|l|l|}
\hline Year & Current ratio of Canara bank & Current ratios of ICICI bank \\
\hline 2013 & 0.03 & 0.09 \\
\hline 2014 & 0.03 & 0.09 \\
\hline 2015 & 0.03 & 0.06 \\
\hline 2016 & 0.04 & 0.13 \\
\hline 2017 & 0.05 & 0.14 \\
\hline
\end{tabular}

Current Ratio

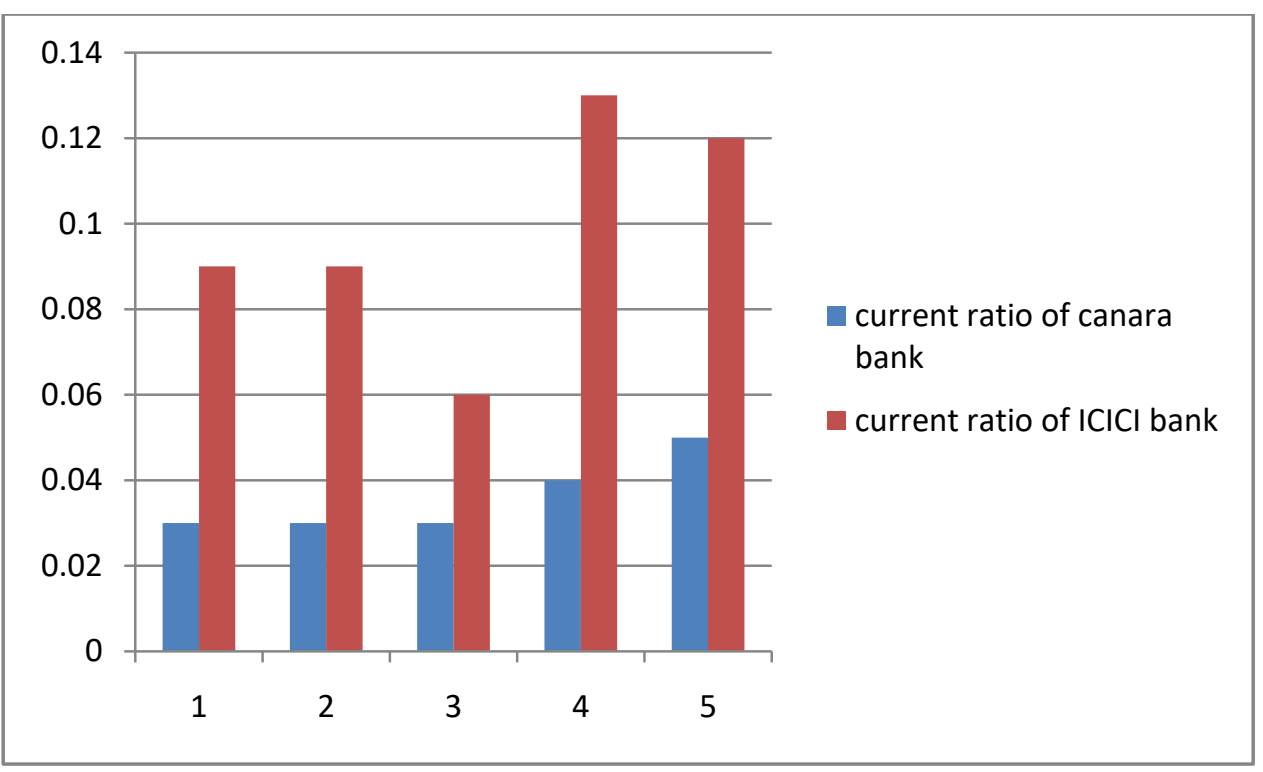

INTERPRETATION: Table shows that current ratio of CANARA bank is same and low (0.03) in 2013-16 and higher in (0.05) in 2017-2018.in ICICI bank current ratio is low and same (0.09) in 2013-2015 and high in (0.13) in 2016-2017. As compare to both the banks current ratio of ICICI bank is more than to CANARA bank, both the banks doesn't reach the standard value.

\section{Quick Ratio}

\begin{tabular}{|c|c|c|}
\hline year & quick ratio of canara bank & quick ratio of ICICl bank \\
\hline 2013 & 23.76 & 10.53 \\
\hline 2014 & 23.4 & 11.31 \\
\hline 2015 & 22.19 & 13.81 \\
\hline 2016 & 25 & 14.97 \\
\hline 2017 & 25.72 & 16.31 \\
\hline
\end{tabular}




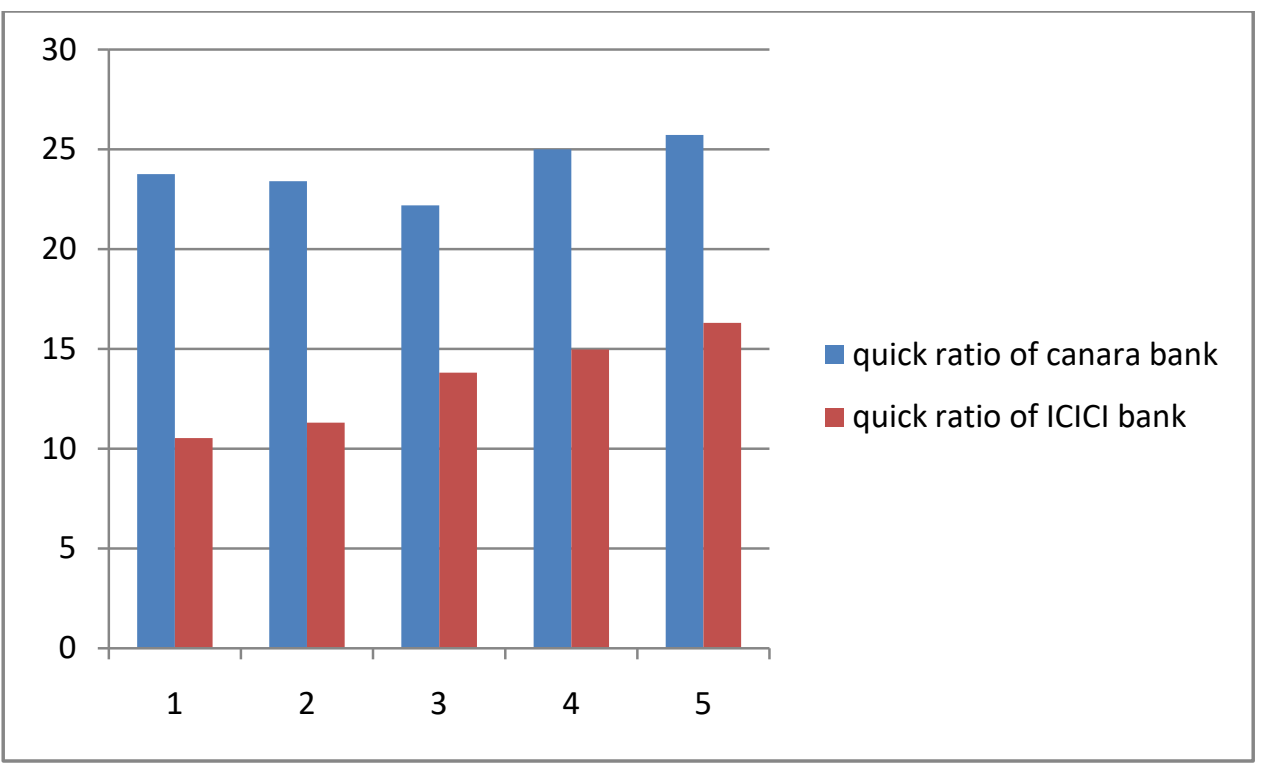

INTERPRETATION: Table shows that quick ratio of CANARA bank is low (22.19) in 2015-16 and higher in (25.72) in 2017-2018.In ICICI bank quick ratio is low (10.53) in 2013-2015 and high in (16.31) in 2017-2018. As compare to both the banks quick ratio of CANARA bank is more than the ICICI bank, the quick ratio of both the banks are satisfactory.

\section{Debt -Equity ratio}

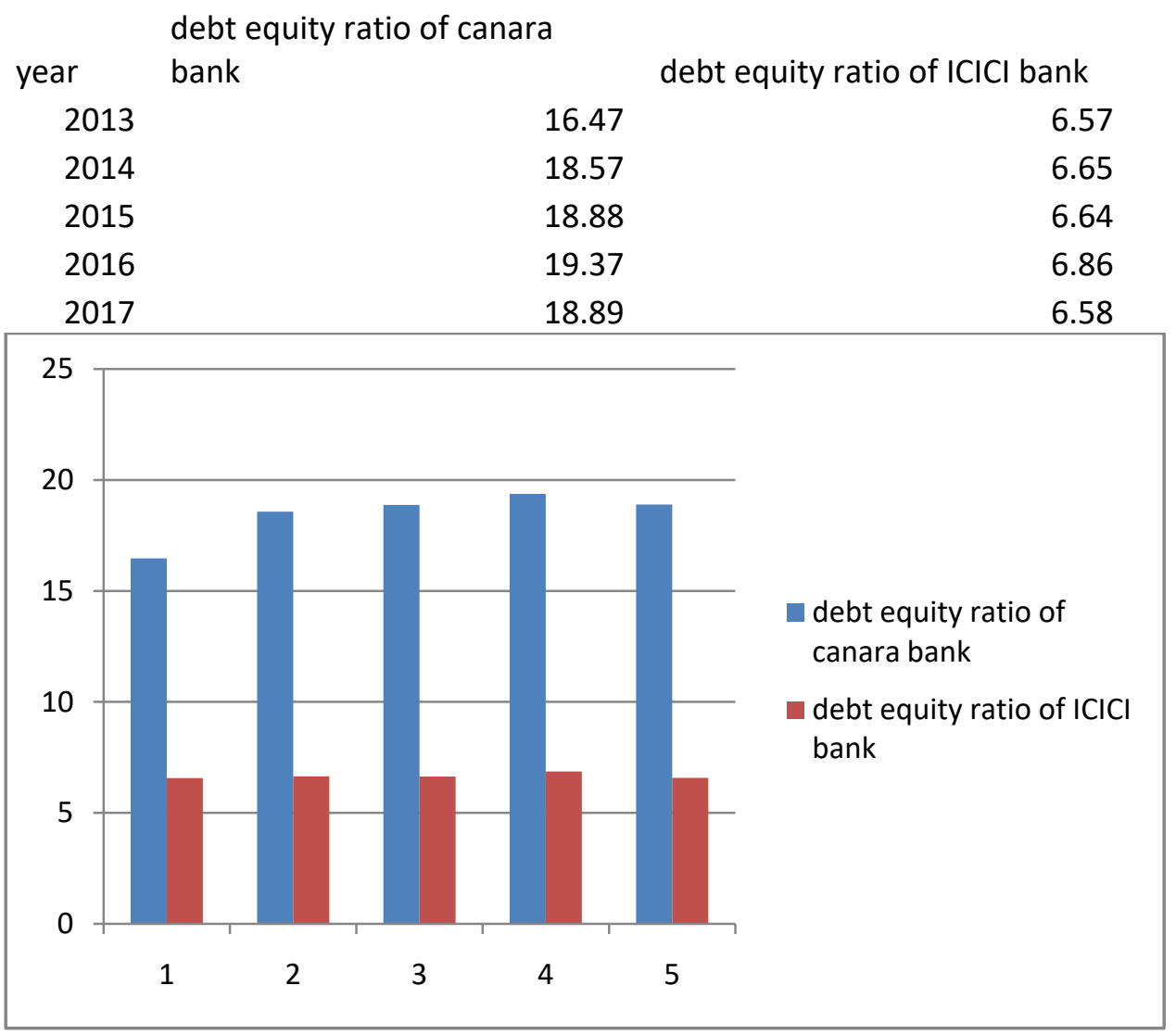


INTERPRETATION: Table shows that debt equity ratio of CANARA bank is low (16.47) in 2013-14 and higher in (19.37) in 2016-2017.In ICICI bank debt equity ratio is low (6.57) in 2013-2014 and high in (6.86) in 2016-2017. As compare to both the banks debt of CANARA bank is taking more debt than the ICICI bank. It shows that a high ratio shows a large share of financing by the creditors of the firm; a low ratio implies a smaller claim of creditors.

\section{Total assets turnover ratio}

\begin{tabular}{rrrr}
\multicolumn{2}{l}{$\begin{array}{l}\text { Total assets turnover ratio of canara } \\
\text { year }\end{array}$} & Total assets turnover ratio of ICICI bank & \\
2013 & 0.09 & 0.08 \\
2014 & 0.09 & 0.08 \\
2015 & 0.09 & 0.08 \\
2016 & 0.08 & 0.08 \\
2017 & 0.07 & 0.07
\end{tabular}

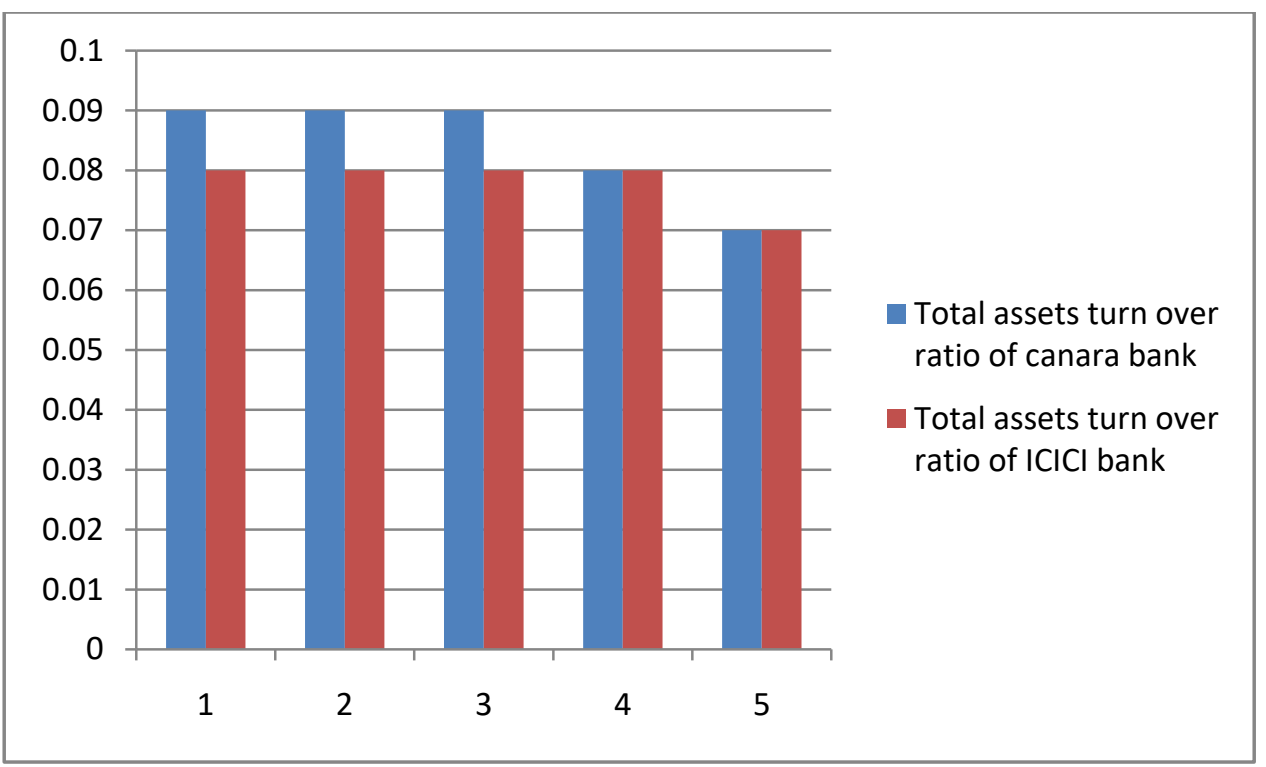

INTERPRETATION: Table shows that Total assets turnover ratio of CANARA bank is low (0.07) in 2017-18 and high and same in (0.09) in 2013-2016.In ICICI bank total assets turnover ratio is low (0.07) in 2017-2018 and high and same (0.08) in 2013-2017. As compare to both the banks total assets turnover ratio of CANARA bank is more than the ICICI bank. 


\section{Net profit ratio}

$\begin{array}{rrr}\text { year } & \text { Net profit ratio of Canara bank } & \text { Net profit ratio of ICICI bank } \\ 2013 & 0.73 & 1.65 \\ 2014 & 0.54 & 1.73 \\ 2015 & 0.53 & 1.8 \\ 2016 & -0.52 & 1.43 \\ 2017 & 0.2 & 1.32\end{array}$

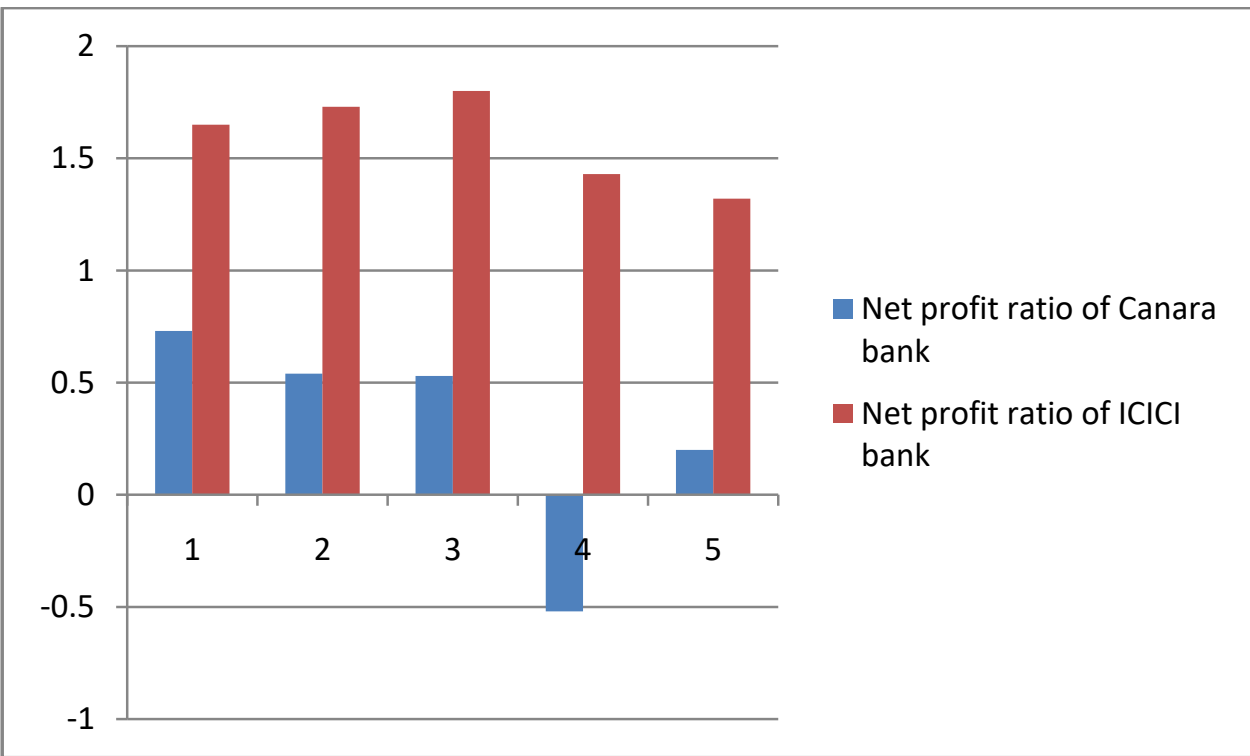

INTERPRETATION: Table shows that CANARA bank is in loss (-0.52) in 2016-17 and more net profit in (0.73) in 2013-2014.In ICICI bank net profit ratio is low (1.32) in 2017-2018 and high in (1.80) in 2015-2016. As compare to both the banks net profit ratio of ICICI bank is more than the CANARA bank.

\section{Findings}

1. Through the financial analysis of CANARA bank and ICICI bank the following findings were done; The ideal current ratio is $2: 1$, but both the banks doesn't reach the standard value, the liquidity of the banks is found to be unfavorable.

2. The Quick ratio of CANARA bank (25.72) is more than the ICICI bank (16.31), itu means CANARA bank is maintaining more Quick assets than the ICICI bank.

3.As compare to both the banks debt of CANARA bank is taking more debt than thev ICICI bank. It shows that a high ratio shows a large share of financing by the creditors of the firm; a low ratio implies a smaller claim of creditors. 
4.As compare to both the banks total assets turnover ratio of CANARA bank (0.09) isu more than the ICICI bank (0.08) it means Canara bank is maintaining good relationship between total assets and sales.

5. As compare to both the banks net profit ratio of ICICI bank (1.80) is more than thev CANARA bank (0.83), it means ICICI is earning more profit than the CANARA bank.

6. As compare to both the banks ICICI bank (85.04) is earning more per share than thev CANARA bank (64.83).

\section{Suggestions}

$\checkmark$ The proportion of current asset to current liabilities should be kept to the standard to do this they will have to either increase the current assets or they will have to decrease the current liability proportion.

$\checkmark$ It is recommended for the banks is to adopt new sales promotional techniques to avoid losses and to increase customer base.

$\checkmark$ It is advice for the banks to make use of all the resources like human resources, and use of technology etc.

$\checkmark$ The banks can serve its customers through multiple channels that are phone banking, internet banking and mobile banking.

$\checkmark$ Activity ratios should be maintained in better position so that it reduces the cost and to increases the profit. activity ratios like debtor's turnover ratio, fixed assets turnover ratio, current assets turnover ratio etc.

\section{Conclusion}

The analysis of the bank was undertaken with the help of ratios, which are important tools of financial analysis. Ratio analysis is a form of fundamental analysis that links together the three financial statements commonly produced by corporations. Ratios provide useful figures that are comparable across industries and sectors. Using financial ratios, investors can develop a feel for a company's attractiveness based on its competitive position, financial strength and profitability. Thus, ratio analysis has been a very useful technique, which has highlighted the performance of CANARA bank and ICICI bank in key-areas and also helped in the avocations of certain strategies to be followed by both the banks which is indispensable to its future growth. 


\section{BIBLIOGRAPHY}

- www.moneycontrol.com

- www.google.com

- www.wikipedia.com

- www.sbi.com

- www.icicibank.com

- Financial management. Pandey, I. (2011). Vikas publishing pvt.ltd.

- Management accounting, Maheswari, S. (2013) New Delhi. 